\title{
State-Society Relations in Ethiopia: A Political- Economy Perspective of the Post-1991 Order
}

\author{
Yeshtila Wondemeneh Bekele *, Darley Jose Kjosavik and Nadarajah Shanmugaratnam \\ Department of International Environment and Development Studies, Norwegian University of Life Sciences, \\ 1432 Aas, Norway; darley.kjosavik@nmbu.no (D.J.K.); n.shanmugaratnam@nmbu.no (N.S.) \\ * Correspondance: Yeshitila.bekele@nmbu.no; Tel.: +25-193-646-2005 \\ Academic Editor: Haider A. Khan \\ Received: 30 April 2016; Accepted: 22 August 2016; Published: 8 September 2016
}

\begin{abstract}
This article analyses state-society relations in Ethiopia with particular emphasis on the post-1991 period. The objective of the study is to identify and analyse the fundamental factors of state-society relations at the national level: property rights, political representation, and the urban-rural elite cleavage. The article views state-society relations at the local level with reference to perception and practice, taking into account symbols, social control, ability to make decisions and control over the means of violence. The study was conducted in eight purposively selected localities in three administrative regions in Ethiopia. The empirical data was collected at national and local levels using key informant interviews, focus group discussions, and a household survey. The analysis shows that state-society relations in Ethiopia are driven by three major factors: property rights, political representations and the urban-rural divide.
\end{abstract}

Keywords: state; society; power; Ethiopia

\section{Introduction}

The top-down nature of modern state formation and nation building in Ethiopia has been much discussed. For instance, [1] argues that state formation in Ethiopia has been driven by force and conquest. It has enabled the state to amass power vis-à-vis society. As a consequence, argues [2] the society would not get the opportunity to choose the type of political system and would not be able to limit the jurisdictional power of the state. Two institutions, namely the state and the church (the Ethiopian Orthodox Church (EOC)), have been identified as the major actors dominating both the structure of power and the control of its infrastructure $[3,4]$. Other social institutions were either too weak, or did not exist, particularly in rural areas. The state and EOC, therefore, were the contending forces for social control via diocese and local governance structures [4]. The EOC was able to establish itself as a paramount power in legitimizing and de-legitimizing state power in pre-1974 politics [4,5].However; the state subdued the church and emerged as the sole dominant structure with overwhelming power in the post-1974 period. After 1991, the state has succeeded in further subduing the EOC by controlling most of the infrastructure of power under its domain. Therefore, the state became the most powerful and dominant actor at national, sub-national and local levels in relation to the other actors.

State-society relations have been characterized by contention, contradiction and domination. Ethiopian society has struggled to limit the power and domination of state. Historically, the Ethiopian society contested the power and authority of the state through peasant rebellion in different provinces (Bale, Gojjam and Tigray), the Ethiopian student movement, the urban uprising that triggered the Ethiopian revolution in 1974, and the long civil war waged between the state and armed groups of EPLF, TPLF, OLF and others [6,7]. However, the state has remained dominant and resilient, coping with the resistance mainly by military and authoritarian means. With the overthrow of the Derg, 
the current regime has introduced ethnicity-based federalism as a way to deal with secessionist challenges. In the Ethiopian traditional context, state and government are not understood as separate concepts or entities. The term "Mengist" denotes a unified concept of sovereignty and the machinery of power [8]. This paper attempts to explore state-society relations in Ethiopia with particular emphasis on the post-1991 period.

The article attempts to answer the questions: what are the driving forces that shape Ethiopian state-society relations? What are the post-1991 political dynamics which have impacted on these relations? How does the state ensure social control in a local arena? How are decisions being made in the local context? How does the state maintain its dominance via monopoly over the means of violence?

We used a structured questionnaire for the household survey and, in addition, open-ended and semi-structured questions for the interviews and focus group discussions. We conducted interviews with selected key informants such as state officials, academicians, politicians, public figures and ordinary citizens. Overall, 38 people were interviewed in Addis Ababa from November 2011 to February 2012, and from December 2012 to March 2013. The recruitment of the key informants was carried out by employing purposive sampling technique; and the interviews were held at the key informants' residences and offices. The interviews with local people were held in their respective localities. Most of the interview sessions and focus group discussions were held at Kebele compounds, for the Kebele officials would not allow the discussions to be held outside the Kebele premises. The selection of informants for the interview and focus group discussion was done with the help of the research assistants.

Likert-scale questions were used for the survey, and the respondents were farmer households who were randomly chosen from the selected Kebeles. The respondents were composed of Kebele administrators, development agents, peasants, and scholars as informed informants of the setting. Accordingly, the quantitative data was collected from a total of 518 households in eight rural Kebeles, which are representing the lowest administrative hierarchy responsible for local administration in Ethiopia.

The study was undertaken in three purposively selected regions: the Southern Nations and Nationalities Regional State (SNNPRS), Amhara National Regional State (ARS) and Oromia National Regional State (ORS) taking into account historical factors, linguistic, ethnic, cultural, geographic, agro-ecology and livelihood diversity. They are three big regional states in terms of demography, territory, economic activities and political dynamics.

Gamo Highlands represents the "Ensete" (false banana)-based livelihood, in the highland agro-climatic zone, where the Gamo minority ethnic group, who are Protestant and Orthodox Christian, are located in SNNPRS. Gamo area represents one of the minority ethnic groups in a multi-ethnic setting of Ethiopian society. The local study areas are: Amarena-Bodo, Ezo-Gulf, and Chano-Mile Kebeles. The livelihoods of local people chiefly depend on roots, tuber crops, and false banana (Ensete) production.

Jimma represents the cash crop-based livelihood, grown on amid land agro-climatic zone, where the predominantly Muslim Oromo ethnic group makes up the majority in ORS. They represent one of the largest ethnic groups in Ethiopia. The local study areas are Gerima, Dawa, and Merewa Kebeles. The livelihood of the local people in Jimma area relies on coffee and "Chat" production.

Deberberhan area represents a grain crop-based livelihood, made possible by low and highland agro-climatic zones, where the Amhara ethnic group is the majority and predominantly Orthodox Christian (members of Ethiopian Coptic Church) in ARS. They are another large ethnic group after Oromo in Ethiopia. The local study areas were Goshen Bado and the Aliyu-Amba Kebeles. The livelihood of the local people depends mostly on cereal crop production.

Primary data from the household survey was analysed using descriptive and univariate statistical techniques including one-sample $t$-test and one-way ANOVAs. Qualitative data collected through interviews was translated, coded and analysed. We also relied on secondary sources for a review and analysis of historical and some current developments. The article comprises four main sections. 
The following section gives a conceptual overview of state-society relations. The third section provides an analytical account of the post-1991 political dynamics, which sets the context to discuss state-society relations in Ethiopia. The final section includes two sub-sections discussing state-society relations in selected rural localities in the three major regions of Ethiopia.

\section{State-Society Relations: A Conceptual Overview}

State and society are two pivotal yet contested concepts in the analysis of political economy [9-11]. State-society relations are generally conceived as a pattern of interactions between the state and society to determine how power is structured, resources are allocated, and rules and controls are established $[9,12]$. State-society relations are implicated in defining mutual rights and obligations, negotiation of power allocation and establishment of different modes of representation, and accountability to each other [13]. The negotiation between the state and society to define their respective roles depends on their access to power. The distribution of power relies on structuration of power relations (agency, actors, network), the exercise of power (power to or power over), and output of the power exercise (domination and subjectification). The power structure represents the hierarchy of decision making and distribution of power among competing actors [14]. The structuration of power is based on power relations which includes access to resources (land and other), right to political representation and control over the means of violence [15]. The power structure thus helps to draw the political landscape of national and local, and the public and private spheres $[9,16]$.

The distribution of power among interacting but competing actors, (social classes, ethnic groups, political forces) via established agencies (constitution, institutions, formal and informal state structures) creates the network of power structure [17]. The network of the power structure enables competing actors to exercise their discretion over one another. Therefore, the power structure sets the ground for power exercise (despotic or infrastructural). The exercise of power according to Mann [18] can be distinguished as despotic power (DP) and infrastructure of power (IP). Despotic power refers to the exclusive exercise of power by elites without involving competing groups/sections of society, whereas infrastructure of power (IP) implies "the capacity of the state actually to penetrate into the society to implement logistically political decision throughout the realm of its territory" ([18], p. 113). The dimension of the infrastructural power is not one-sided but encompasses multiple actors.

The capacity of the state, therefore, depends on the growth of its infrastructural power. The infrastructural power in the context of our study is conceptualized as the capability of the state to enforce its authorities and implement its policy; capacity to have control over the means of violence or coercive forces; ability to maintain state symbols that reflect its authority; and command over social and political controlling mechanisms.

State-society relations involve the overall power relations and interactions between the central state and local society regarding access to resources, exercise to political power and control over the means of violence. This article, as stated elsewhere, seeks to explore an emerging trend of state-society relations inpost-1991 Ethiopia. This period is remarkable in Ethiopian politics for the following reasons: firstly, the second republic was established by replacing the centralist military state with an ethnicity-based federal political structure. Secondly, the introduction of ethno-regional federalism resulted in the rise of rural elites vis-à-vis urban elites and the control of the state by the former. Thirdly, the Ethiopian state enormously expanded its infrastructural power to the rural localities through the incorporation of emerging elites into the local state apparatus. This infrastructural power included various formal and informal institutions, such as the government wing, party wing and popular wing, as we shall discuss in this article. These power infrastructures give absolute power to the state over society and signify the gradual rise of an authoritarian state with a character of strong state and weak society. The Ethiopian state today is characterized by contradictions. It displays the character of a democratic state through participation and incorporation of competing groups and procedural elements of democracy. It also exhibits an authoritarian character with a strong state capable of controlling the economy (extracting resources, revenue generation, controlling the market, 
expanding infrastructure), security (capacity to deploy repressive power), and politics (total control over state apparatus from lower level to higher level of administration). The current Ethiopian state exhibits a typical character that, as noted by [18], is the characteristic feature of an authoritarian state by exercising high levels of despotic power (DP) and infrastructural power (IP).

\section{The Post-1991 Dynamics: Political Transformation and Continuity}

Scholars like [19-21], present the post-1991 political dynamics in different chronological order. ${ }^{1}$ However, we identify the political order of the post-1991 period in four phases: regime transition, consolidation, domination and contestation. The first phase spans the years between 1991 and 1997, encompassing an attempt at political transition to a democratic system through reconstruction of the state and adopting the new constitutional order. Accordingly, three radical types of reforms were undertaken: decentralization of the state, democratization of politics and liberalization of the economy [22]. The new federal constitution that was established upon a structural foundation for post-1991 state-society relations was ratified in 1995 [23]. It sets out a new federal arrangement based on ethnic identity, bestows popular sovereignty on ethnic groups, and endows self-determination rights including "the right to secessions" to nationalities [24-28]. In the following figure (Figure 1), we represent the post-1991 political dynamism in Ethiopia in chronological order.

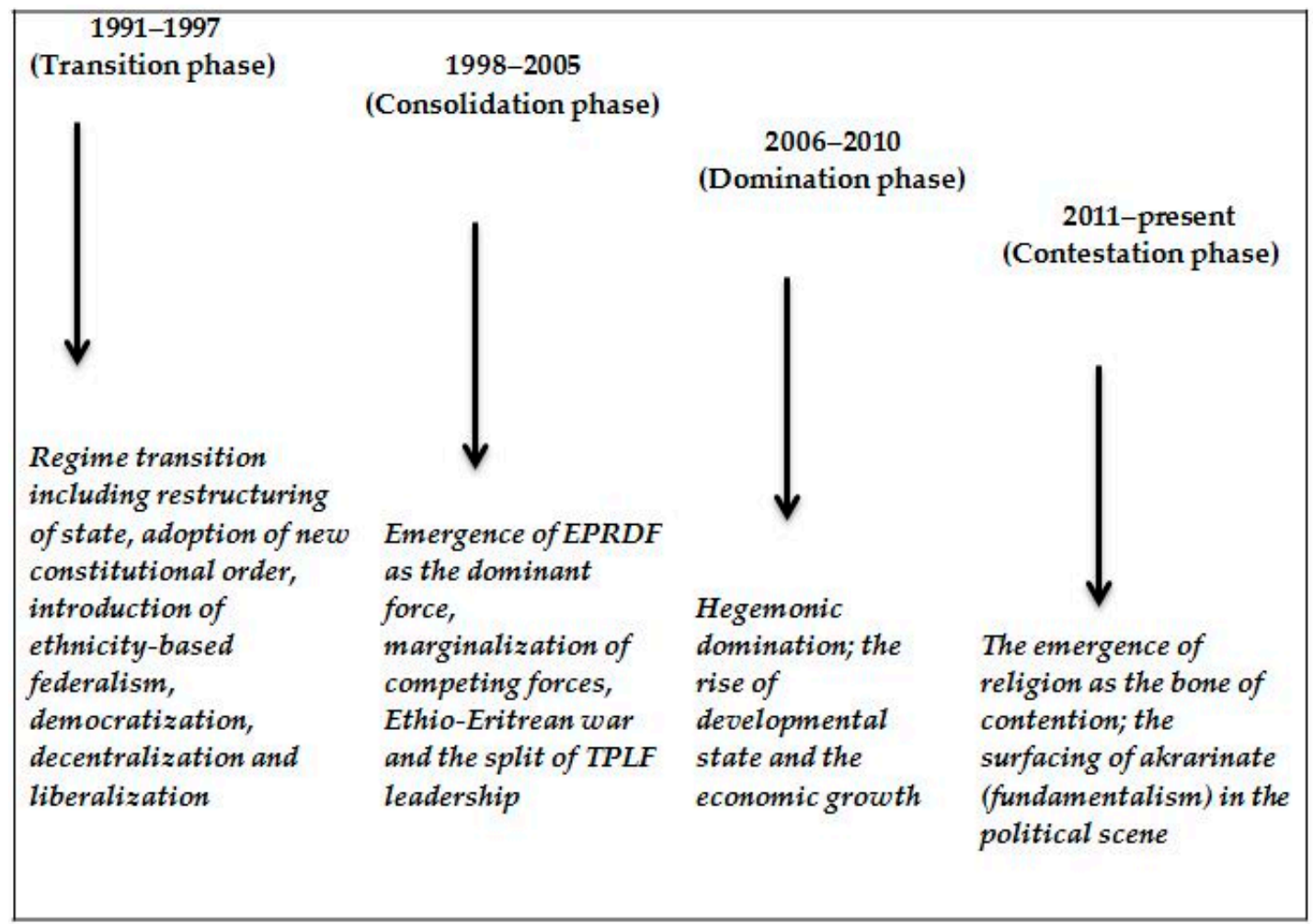

Figure 1. Post-1991 political dynamism in chronological order; source: developed by authors.

The second phase covers the years between 1998 and 2005, which signal the rise of EPRDF as a single political party. EPRDF established itself as the strongest political force [29-31]. The fledgling political forces were either eliminated or appeased, partially as a result of their weakness and partly because of unfriendly political ground. EPRDF emerged as the strongest political force by attracting

1 The post-1991 political order is unique in the sense of restructuring the Ethiopian state along ethnic federalism and promoting cultural pluralism of competing ethnic groups. Both factions have negated the idea of pan-Ethiopianism (a unified and single Ethiopia) and uphold ethnic nationalism. 
regional elites and expanding its sphere of influence. However, the 1998 Ethio-Eritrean war disrupted the consolidation efforts. In fact, EPRDF was able to become triumphant in the war effort from a military standpoint. However, it faced a major diplomatic setback that severely downgraded its legitimacy [32]. During the course of the war, the society entrusted EPRDF with full legitimacy to defend the sovereignty of the state. Consequently, EPRDF had amassed widespread popular support for the first time since it had come to power. However, the EPRDF was unable to take full advantage of this support to enhance its legitimacy, due to the split within TPLF among senior ranking officials ${ }^{2}$ [33]. The split within TPLF significantly damaged the strength of the ruling party and set the Ethiopian state on a new political course [32].

The third phase, hegemonic domination, covers the period from 2006 to 2011. It was characterized by EPRDF's hegemonic domination of the political realm. In the 2005 election, EPRDF lost a considerable number of parliamentary seats but was determined to retain power and supreme command by sending opposition political leaders, accused of masterminding the post-election crisis, to jail. Furthermore, the government adopted various laws and decrees to give more power to the state to control the activities of civic and political organizations [19,34,35]. All in all, the state tightened its grip over power by adopting a new ideology of developmentalism ${ }^{3}$ over the existing ideology of revolutionary democracy.

The rise of EPRDF to hegemonic status and the virtual weakening of opposition political forces prompted the beginning of the fourth phase (2011-present) in which religious institutions, particularly Islamic, emerged as contending forces against the state authority. The dwindling of political force has prompted religious groups to fill the space left by political parties and to emerge as an alternative social force. The shrinking political space paved the way for the emergence of religious institutions as alternative means of articulating societal interests. ${ }^{4}$ This has resulted in rivalries within and between religious groups, and between the latter and the state. The so-called Amharic term "akerarenate" for religious fundamentalism emerged as a catchphrase of state-society relations in the post-2011 period. The state has mobilized considerable resources and used its authority to deal with the emerging challenges. However, religion has gradually emerged as a potent force in state-society relations.

\section{State-Society Relations in Ethiopia: Property, Representation and Identity Rights}

State-society relations in Ethiopia can be viewed from two broad perspectives, namely struggle over property rights and political representation. These have been driving national politics, framed as questions of "land to the tiller" and "national equality," since the 1960s. 5 The first question represents the economic power and the second question signifies the political power of society. Both questions concern power and property rights of the society. The resistance against the state in relation to these major questions first permeated from various peasant movements. They were further articulated in student movements and later culminated in various ethnicity-based liberation struggles [6,36,38].

As [33] notes, the 1960s and 1970s generations problematized the contradiction between state and society in the pre-1974 period, as emanating from economic exploitation based on the land tenure regime. The common solution proposed by the student movement for the problem was radical land

2 In the wake of the Ethio-Eritrea war (1998-2000), the TPLF senior officials split into two groups, dividing as Yemeslse buden (Prime Minister Meles Zenawi’s team) and Yeanjawu buden (the contester team). The cause of the split was differences over how to deal with the war and dissatisfaction with Zenawi's leadership in the war. The squabble and power struggle continued for a month. Later, Prime Minister Zenawi's team emerged as a winner [32].

3 After 2005, EPRDF introduced the new ideology of the developmental democratic state. Meles Zenawi (the late prime minister) was considered as the mentor of the new ideology. The new ideology undermines Western neo-liberalism and espouses the Chinese model of development, which puts state at the centre of any development activities.

4 The movement of the Muslim community (demestachen yesema-our voice to be heard) which started in Addis Ababa with small-scale opposition following the arrest of the Muslim leaders, snowballing into a nationwide movement, is an example of this case. In the same way other religious groups too gained popular support.

5 The questions of "land to the tiller" (Meretlarashu) and "equality of nationality" (Yebeher equlenet) had surfaced in Ethiopian politics in the mid-1960s. It caused the 1974 revolution that overthrew the Haile Selassie regime [36,37]. 
reforms and peasant ownership of land. The military regime in post-1974 took radical measures of nationalization of land in line with this proposition. ${ }^{6}$ However, the contradiction persisted without a solution. It prompted the collapse of the regime in 1991. The TPLF/EPRDF regime brought another problematization of the inherent contradiction as "the question of nationality." This question emerged as a super-structural factor, which demands a new social pact to ensure social equality and the restructuring of state-society relations. The regime adopted an ethnicity-based federalism that endows regional autonomy and shared governance by devolving power from the centre to the regions as an accommodative means of national representation [41].

National representation and power sharing are key structural issues in state-society relations. The debate is centred on what kind of representation modalities and power-sharing formula the country should adopt. Some scholars and politicians advocate individual-based representation that echoes the liberal principle of citizenship. Others argue for ethnicity-based federation as a viable means of accommodating competing interests of diverse ethnic and linguistic groups [24,28,42].

The attempt to install political representation based on citizenship failed because of the contrasting approaches of the state and society. The society has not evolved into a cohesive national unit in spite of successive social engineering efforts, nor has the state been willing to relinquish its monopoly of power through devolution and power-sharing arrangements. Since the advent of the modern state, the state-society relations have become positioned as crown/subject and state/subject. Although basic and fundamental rights of individuals have been bestowed in all modern legal provisions, particularly in written constitutions since 1931, the state has also had a right to revoke these rights [27,42]. The failure to establish effective and functional citizenship institutions has aggravated the prescription of ethnicity as an indispensable means of representation and political settlement.

As [35] notes, ethnicity has been embedded in the political economy of the country. The origin of ethnicity can be traced to diverse discourses on the history of ethnic and cultural inequality $[24,26,27,42]$. In the past-mainly during imperial times-ethnic groups had rank and favour in relation to access to state resources in line with their affiliation to Amhara and Orthodox Christian culture [35]. The blatant political and cultural inequality sparked debates on the nationality question, as well as activism among students in the 1960s, eventually galvanizing into the ethnic politics of different ethnicity-based liberation movements [31]. Ethnicity, thereafter, has occupied the centre stage of national politics. Most of the political forces which were established in the aftermath of the 1974 revolution were ethnicity-orientated.

In the post-1991 period, the TPLF-led EPRDF regime took control of state power and established an ethnicity-based federalism [28]. Under the new statehood, the power structure was reinvigorated along with the rise of new regional ethno-elites, but TPLF has been able to maintain its political, economic and military hegemony at the centre [2,29]. The reconstruction of the ethno-political state marked the remaking of political representation and power-sharing based on ethnicity.

Another contested domain in state-society relations is property rights and resource allocation. The Ethiopian state historically has had a heavy hand over property rights. All successive states have advocated for state ownership of key resources. They have also placed private property under control of the state. Control over property is used as an effective means of social control. The issue of land tenure ${ }^{7}$ is a case in point. Since the formation of the modern state in Ethiopia, land has been

6 Negarite Gazeta (1975) is a proclamation to provide for the nationalization of rural lands (No. 31) and a proclamation to provide for the nationalization of urban land and urban housing (No. 41), Addis Ababa, Ethiopia ([39], pp. 200-14; [40], pp. 93-101).

7 The land tenure system in Ethiopia is one of the most controversial issues. Before 1974, the tenure system included Rist, Rist-gult, and Gult. The rist system was a kind of corporate ownership system based on descent that granted usufruct rights - the right to appropriate the return from the land. In the rist system, all male and female descendants of an individual founder or occupier were entitled to a share of land [43]. Gult right refers to a fief right that required the occupant of specific rist tenure (or those who held other types of traditional land rights) to pay tribute and taxes in cash, kind, or labour to landlords. Gult rights were not inheritable or not necessarily hereditary [44,45]. Rist-gult right is an exclusive right vested on royal families and provincial lords who have the right to independently levy taxes in cash, kind, and labour [46]. 
under state control [1,47-49]. Successive regimes have not been willing to relinquish control over land. Regimes have also been adamant about establishing a strong institution of private property. The underlying rationale is the inherent lust for monopoly over power and resources. In Ethiopia, land is the predominant source of economic power to create wealth, attract clients and to sustain institutions. From the perspective of state-society relations, both land tenure and property ownership are crucial aspects in empowering society and maintaining balance of power. It is evident that land and control over property ownership give absolute power to one or the other (state or society) to dominate and maintain its influence [31,33].

Besides the two dominant perspectives of national representation and property rights, we have identified a new and third perspective: the urban-rural cleavage. The political struggle, according to this perspective, spins around recurrent antagonism between the rural and urban elite. The urban-rural cleavage, which is centered on socio-economic differences, has been a fault-line of political alignment as Getere/balager (countrymen/women) and Keteme (urban men/women). This political dichotomy can be traced back to the evolution of urban centres in early twentieth-century Ethiopia.

Major urban towns were established in the beginning of the twentieth century as military garrisons, which later evolved into modern urban and administrative centres. The majority of dwellers are Amhara, Oromo, Tigre, and Gurage who settled in these areas as soldiers, priests, merchants, and civil servants. The rural elite consider urban areas as strong bases of these ethnic groups, particularly the Amhara elite. The elites from urban areas dominated the political scene since the formation of the modern state because of access to education and modernization. They predominantly advocate pan-Ethiopianism and constitute the prominent intellectuals, authors and artists. They either have urban origins or have become accustomed to the urban life and widely represent the urban sentiment. Conversely, the expansion of modern education and the penetration of state into the rural areas gradually changed the power configuration with the rise of rural elites who represent the rural masses and mostly constitute the political elites. The contention between these two segments of the society, intellectuals and political elites, seems to drive and shape state-society relations. Consequently, their struggle for political power resulted in unprecedented political dynamics in the post-1991 period. As one politician noted:

The centrifugal force of Ethiopian politics and Ethiopian society since 1960 is an irreversible dispute between the urban and rural elite. Both are fiercely fighting to justify their cause in noble ways using ethno-nationalism and civic nationalism. It seems that the rural elite are gaining dominance and restructuring the very nature of Ethiopian society along ethnic lines. However, the remarkable thing is most people could not recognize the hassle behind ethnic politics [50].

The main cause of the irreconcilable differences is the way both parties have been portraying each other. The urban elite portray themselves as modern, educated and progressive, while caricaturing the rural elite as uneducated, uncivilized and conservative. The rural educated elite Geteres (countrymen/women) or Yearsoadere Lijoch (the sons/daughters of farmers) retaliate to the urban narration by depicting the urban elite as remnants of Amhara chauvinists. Some of the norms that were set by urban elites to be considered as modern include the ability to be articulate (first and foremost), resonation of pan-Ethiopian sentiment, flexibility to adopt modern ideas, level of education and urban-orientated lifestyle. The majority of the urban elite is drawn from the main urban cities in Ethiopia and represents the highly educated social section.

This dichotomy prompts the rise of contrasting culture and the creation of divergent identities and mentalities framed in terms of ethnicity. Ethnicity emerged as a driving force of organization and mobilization of the rural elite. It would seem that they have been dominating politics since 1991 by redefining and deploying ethnicity as a weapon to assert their power. This is evident in the fact that the rural elite have been able to control the state machinery in the last two decades under the EPRDF-led government. 
The EPRDF-led government preferred to build up the state machinery using the rural elite for two reasons. First, the urban elite have contested the EPRDF idea of cultural pluralism and ethnicity-based political settlement, whereas EPRDF under the leadership of TPLF sought to deconstruct the notion of statehood based on pan-Ethiopianism by so-called Shewan nobles. ${ }^{8}$ Second, the rural elite using the political spaces provided by EPRDF were able to organize various political parties and mobilized the rural masses under different ethnicity-orientated organizations (PDOs). ${ }^{9}$ The new government used these satellite organizations to construct its legitimacy. It initiated the policy of agriculture-led industrialization (ADLI) which places the rural peasant at the centre. Consequently, the influence of the urban elite is gradually diminishing, following their mass exodus to Europe and the United States as the Diaspora community. The urban elite have, therefore remained as a backbone of the Diaspora community known for contesting the state in power.

\section{State-Society Relations in Rural Ethiopia}

\subsection{Perception and Symbols of the State: Kawo, Motuma, and Mengist}

The post-1991 local governance structure in Ethiopia comprises five tiers of administration: the federal state (federal), national regional state (Kililoch), provincial administration (Zonal), district (Woreda) and neighborhood or peasant associations (Kebele). The Kebele is the lowest level of local administration. The rural households under Kebele administration are typical nuclear families closely interconnected and interacting [34]. The Kebele represents the state in the local community and serves as a platform of interaction. It is run by elected local peasants. Most of the local officials can barely read and write and they serve on a voluntary basis. However, they wield substantial power in relation to land administration and preserving social order in their respective localities [53].

Our study concurs with previous findings regarding the image, symbol and authority of the Ethiopian state. It is well-embedded and respected in the rural localities; local society firmly respects symbols of the state authority. ${ }^{10}$ Likewise their perception of the state is very strong. In the study areas in Gamo highland (SNNPRS), the local people recognize the state as Kawo (local word for king). They believe that the power of the state is inviolable and uncontested. They consider the state as "the bearer of life," [54] and have faith in maintaining an eternal obligation to be obedient and loyal to the state. They praise the state as the provider of life, peace, and order and rarely question the power of local authorities. They seem to be loyal to and fearful of state power. It is possible that they may have developed this belief from the feudal legacy and subsequent suppression by successive regimes.

In the study area Jimma (ORS), the local people describe the state using the local language of Oromifa as Motuma (government/state). They believe that government is an outcome of the society and people are the ones who constitute it. However, they recognize that society cannot exist without state and state has a responsibility to organize and lead the orderly life of the society. As one farmer noted:

We elect the government and we make the state. However, the state decides our fate and organizes our life. We give our power to the state for the common good of our life.

Otherwise our lives might be in jeopardy [55].

8 Pan-Ethiopianism represents a unique socio-political and cultural character as being an Ethiopian. It is believed to be constructed by Shewa nobles following the incorporation of the southwestern and southeastern part of present Ethiopia. It is contentious for having two dimensions. Externally, it is widely revered by many populations of black-African origin primarily from the Caribbean and North America, as a symbol of redemption and independence [51] Internally, it is considered devious and branded among contending ethnic groups, mainly by Oromo and other minority ethnic groups, as the symbol of domination. [52].

9 PDO refers to Peoples' Democratic Organizations. During the Transition Period (1991-95) different ethnic groups created this kind of political organization in an attempt to get representation in the new government.

10 In Ethiopian traditional context, state and government are not separate concepts. The term Mengist denotes a unified concept of sovereignty and the machinery of power [54]. 
It is evident from this farmer's remark that the local community has respect for the powers of the state. Although they consider themselves as having constituted it, they still believe that the state is responsible for organizing workable functional institutions to coordinate, provide and lead their lives.

In the study areas in Deberberhan (ARS), the local people refer to the state as Mengist (Amharic word that refers to state). From the focus group discussion and interviews, which were held with farmers, we found that the symbol of the state is deeply embedded in the social structure. One farmer commented:

State is the essence of our life. Without state we cannot work, we cannot trade and send our kids to school. The moment we lose the state, we start killing and robbing each other. We can have only peaceful and prosperous life so long as the state exists [56].

The farmer's remark resonates with the Hobbesian essence of the state. ${ }^{11}$ In the focus group discussions and interviews with farmers, we found that they all shared a similar view. The farmers are not educated but they understood the basics of the state. For example, there are some properties in these localities, which belong to the state but are not properly guarded. Surprisingly, no one trespasses into these properties simply because they belong to the state. The symbolic presence and the subsequent perceptions about the state are very strong. Furthermore, it would seem that farmers in these localities believe in a hierarchical structure of relations that always places the state at the top of society and makes the society obedient to the state's will. Otherwise they argue that the so-called effective state will never exist. Their view concurs with previous studies $[34,48,58,59]$ indicating that state is regarded as the most powerful entity in rural Ethiopia.

\subsection{The Practice of State: Social Control, Decision-Making and Control over Means of Violence}

The Kebele structure and organization have undergone swift reforms after the 2005 election crisis. The EPRDF-led government has introduced a well-maneuvered decentralization scheme and instituted the appointment of salaried managers to the Kebele administration [60]. The managers are modestly educated and assigned to the Kebele office by Woreda officials. They are supposed to carry out administrative routines of the Kebeles. Besides the appointment of Kebele managers, the state has increased its penetrative capacity overwhelmingly through different sets of complex social control mechanisms. One of the political controlling mechanisms is a multiple layer of political and social organizations named as party, government and popular wings [52].

Almost all peasants are grouped under the new hierarchical social organization since 2008. In fact, the structure and naming of these social organizations differ from region to region. In SNNPRS, the new social organizations consist of Hewase (cell or network), Yelmatebuden (developmental team), Gote (sub-village) and Kebele (peasant association). Hewase implies a grouping of five peasant households under one leader. It is also known as "one to five." Yelamtebuden consists of five Hewase, and Gote comprises four to ten Yelmatebuden. A Kebele consists of five to seven Gote.

In ORS, the social organization consists of networks (five households), Gere (six networks), zones (ten Gere), and Kebele (six zones). As we can see from figure 2, these social organizations comprise a complex nest in rural Ethiopia that spans all Kebeles. The leaders of these popular organizations are model arsoaderoch (model farmers). The following figure (Figure 2) indicates the new Kebele organization after the introduction of the complex social organization.

11 The Hobbesian view implies the social disorder and the brute situation of a state of nature; "the war of all against all"could be avoided only by a strong, undivided state [57]. 


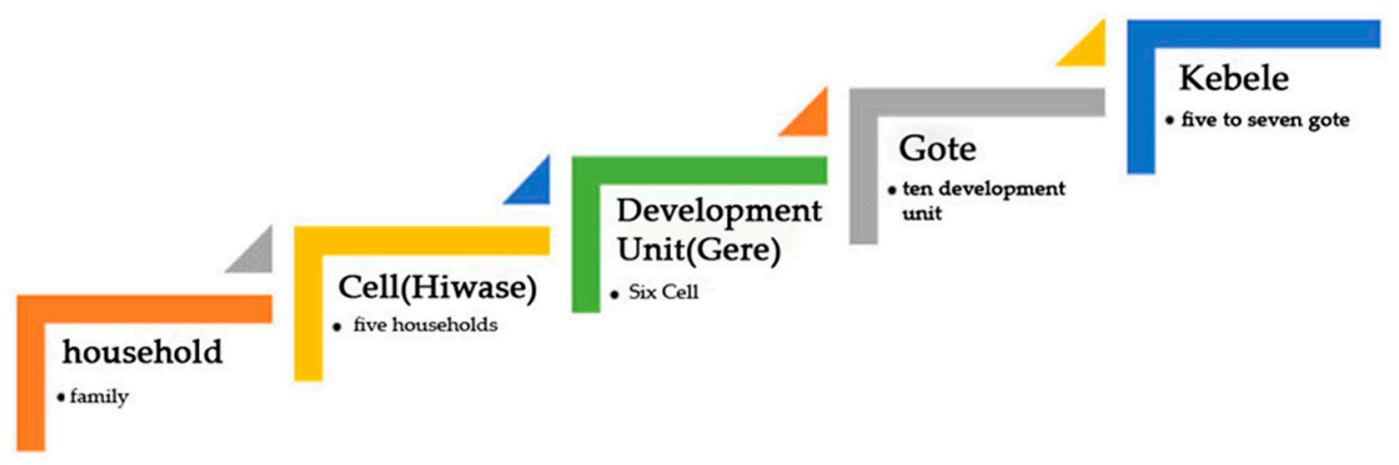

Figure 2. Local governance sub-administration structure; source: developed by authors.

In focus group discussions and interview sessions, several peasants confirmed the significance of inclusion in this organization from two standpoints. First, unless they are included in this organization, they are not entitled to benefits and assistance from the government such as selected seeds, fertilizers and technical assistance. Second, these organizations are very helpful in terms of enhancing cooperation, collaboration, learning from each other and solving problems in a common understanding. From the discussions, it would seem that most peasants are in favour of the organization. As one peasant argues:

The popular organizations are quite helpful to support each other, learn from each other, work together, mobilize the community in conservation; water shed management and maintain security of the locality. We are being organized in popular wing (heizebawikenfe), governmental wing (Mengistawikenfe) and party wing (derjetawikenfi). All these three broad organizational chains have created interconnectedness and interdependence among the local communities [61].

However, the scholars and opposition politicians interviewed for this study expressed their fear that the state is establishing a kind of complex controlling mechanism that goes down to the household level. Accordingly, these organizations are designed by the government as new control technology to prevent the opposition from getting a foothold in rural areas where EPRDF claims its power base is located. Whatever the case, the state has a strong presence and has expanded its penetrative and extractive capacities in rural Ethiopia enormously after 2005. Besides having the upper hand in social control, the state has also predominance in decision-making, agenda-setting and control over the means of violence, as we shall discuss in the next paragraphs.

Ability to make decisions, capacity to set agendas, modes of accountability and control over the means of violence are widely believed to be manifestations of the exercise of power and power relations. We used these variables to assess the balance of power and power relations between state and society in the rural realms. We shall discuss the survey results in the next paragraphs.

The respondents for questionnaire survey were farmer households who were randomly selected from the selected eight Kebeles. The socio-economic background of the respondents of the household survey is given in Table 1 below.

Table 1 shows that the majority of respondents are male $(93.2 \%, \mathrm{~N}=483)$, and their occupation pattern (livelihood) is based on agriculture $(92.5 \%, \mathrm{~N}=479)$. In terms of education, most of the respondents are primary school dropouts $(45.8 \%, \mathrm{~N}=237)$ and others are illiterate $(42.9 \%, \mathrm{~N}=222)$. About a third $(29.6 \%, \mathrm{~N}=154)$ of the households earn a monthly income below 300 Ethiopian Birr (USD 15.8). Nearly $80 \%$ of the respondents described their income as less than USD 30. 
Table 1. Socio-economic background of respondents $(\mathrm{N}=518)$.

\begin{tabular}{cccc}
\hline Background & Category & $\mathbf{N}$ & $\mathbf{\%}$ \\
\hline \multirow{2}{*}{ Occupation } & Farmer & 479 & 92.5 \\
& Other & 39 & 7.5 \\
\hline \multirow{2}{*}{ Education } & Illiterate & 222 & 42.9 \\
& Primary & 237 & 45.8 \\
& Secondary and & 59 & 11.3 \\
& above & & \\
\hline \multirow{2}{*}{ Gender } & Male & 483 & 93.2 \\
& Female & 35 & 6.8 \\
\hline \multirow{3}{*}{ Household income (in ETB) } & $<100$ ETB & 118 & 22.8 \\
& $101-300$ & 154 & 29.7 \\
& $301-500$ & 124 & 23.9 \\
& $>500$ ETB & 122 & 22.6 \\
& Total & N $=$ & $100 \%$ \\
\hline
\end{tabular}

Source: Survey data by the authors (2011/2012).

Most local people who took part in the focus group discussions emphatically expressed their unreserved right to make decisions regarding their domestic matters. Some people in the Gamo area mentioned the bestowed constitutional right of using local language: "hegemengitse emeda meabete." The overall survey results presented in Table 2 show that $62.7 \%(\mathrm{~N}=227)$ of the respondents believed that they had a right to make decisions in local matters, $16.4 \%(\mathrm{~N}=85)$ strongly agreed and $46.3 \%$ $(\mathrm{N}=240)$ agreed, while $39.6 \%(\mathrm{~N}=206)$ neither agreed nor disagreed.

Table 2. Respondents' views of power relations at local level $(\mathrm{N}=518)$.

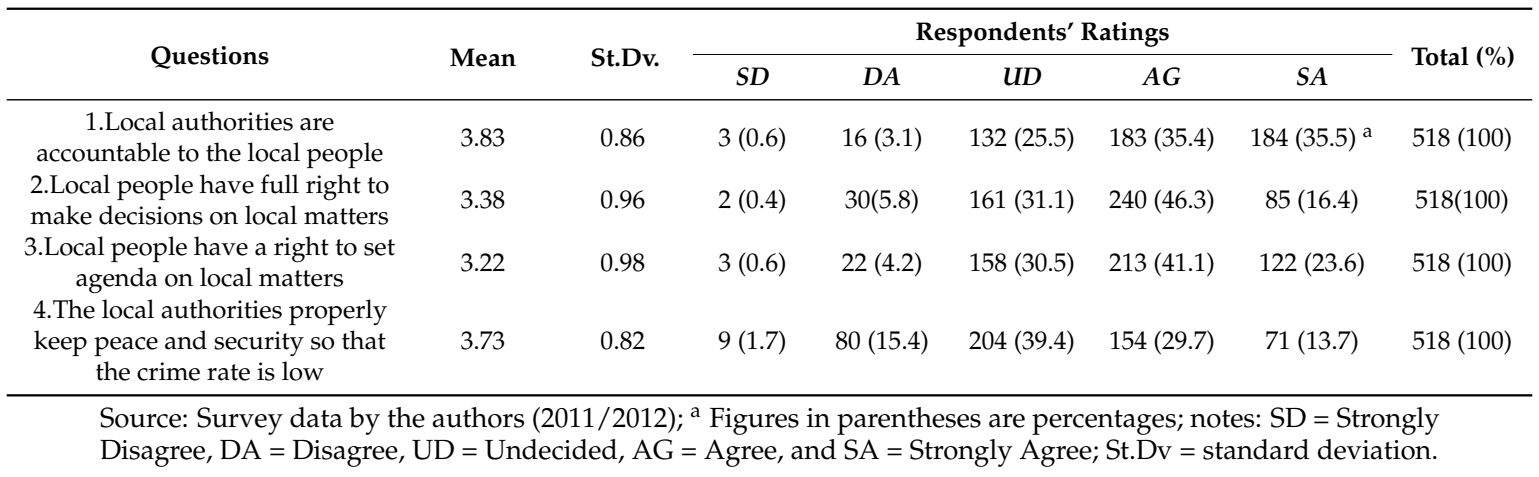

In the informal discussions, however, some of the respondents in the Gamo areas spoke of the level and extent of their powerlessness in local matters as follows:

We do not have any rights in this land. Kawos decides everything. My family's fate and existence depend on the will of Kawo because we got land, selected seed, credit and assistance from our Kawo. Our Kawo is even more powerful than God in our land [62].

One of the peasants stated that, although they were not happy with the situation, they refrained from expressing grievances in fear of repression and subjugation. It would seem that the pattern of master and tenant relations, which has been inherited from the old feudal tradition still persists. The state power seems to be largely uncontested in the study area.

The participants described yemetoshengo (local council) and the local administrative structure as modalities of participation and decision-making in their local affairs. The local authorities also explained that the local democratic process was direct and inclusive, providing a wide arena of 
participation in decision-making using local councils as a platform of participation and inclusion of the local people. A similar concern which arose from focus group discussions, interview sessions and questionnaire survey was whether the local people had a mandate to set agendas on their domestic problems and to make decisions accordingly.

As can be seen from Table 2 above, $65.7 \%(\mathrm{~N}=325)$ of the respondents agreed that the local people have the capacity to set the agenda. A further $4.8 \%(\mathrm{~N}=25)$ disagreed and $30.5 \%(\mathrm{~N}=158)$ were undecided. The findings of the survey contradict the local people's responses in focus group discussion regarding agenda-setting. More than two-thirds of the focus group participants believed that they did not have a mandate to set agenda in developmental, security, welfare and other affairs of their locality. All agendas, except some social issues of local interest, were sent down from the district authorities or higher authorities, and even discussed through yehezbawi aderejajet (popular organizations). Taking into consideration the two factors of decision-making and agenda-setting, it appears that the state wields overwhelming power over the local people.

The survey results given in Table 2 indicate also the accountability of the local officials, both upward (administrative) and downward (political). Regarding downward accountability, 70.9\% $(\mathrm{N}=267)$ agreed that local authorities are accountable to them with $35.4 \%(\mathrm{~N}=183)$ agreeing and $35.5 \%(\mathrm{~N}=184)$ strongly agreeing, while $25.5 \%(\mathrm{~N}=132)$ are undecided on the matter. Only $3.7 \%$ $(\mathrm{N}=19)$ disagreed that local officials were accountable to the people. However, the interview and focus group discussion results again indicated that the local officials were not accountable to the local people. Rather, they were accountable to the district officials. A further statistical analysis using a one-sample $t$-test (see Table 3) confirms this finding as discussed below.

Table 3. One-sample $t$-test on respondents' views on power relations (test value $\left.=4^{\mathrm{a}}\right)(\mathrm{N}=518)$.

\begin{tabular}{cccc}
\hline Items & Mean & SD & t \\
\hline 1. Local authorities are accountable to the local people & 3.83 & 0.86 & $-4.56^{*}$ \\
2. Local people have full right to make decisions on local matters & 3.38 & 0.96 & -14.62 \\
3. Local people have a right to set agenda on local matters & 3.22 & 0.98 & -18.12 \\
4. The local authorities properly keep peace and security so that the crime rate is low & 3.73 & 0.82 & -7.637 \\
\hline
\end{tabular}

${ }^{*} p<0.05$; source: survey data by the authors $(2011 / 2012)$.

The results of the one-sample $t$-test in Table 3 indicate that (where the test value $=4$ or agreement with the statements were taken as criteria for comparison with the means), they were statistically significant with the minimum t-value obtained in the case of the first item: "accountability of local authorities" to their constituencies (mean $=3.83, \mathrm{SD}=0.86 ; \mathrm{t}(157)=-4.56, p<0.05)$, while the maximum $\mathrm{t}$-value was found in the case of the third item: "local people have the right to set agenda on local matters" (mean $=3.22, \mathrm{SD}=0.98 ; \mathrm{t}(157)=-18.12, p<0.05$ ). These findings suggest that in relation to the four indicators of power relations, regardless of differences in terms of region, gender, educational status, and income levels, the respondents rated the performance of local authorities as below the level expected. In particular, a closer look at the mean scores (all means less than 4.00, meaning agreement with the affirmatively worded statements) and the corresponding statistically significant negative t-values (ranging between -4.56 and -18.12), show generally unfavorable ratings in all the four aspects of power relations. Table 3 presents mean score of variables in three regions as follows:

As we have seen from Table 4, respondents from the Amhara regional state gave lower rating for all variables as compared to the other two regions. However, possible statistically significant differences in the average value will be examined later in this section.

As part of the study, the extent to which the background characteristics of the households-household head's gender, educational status, region, and income level—have significant effects was examined. The table (Table 4) summarizes the univariate ANOVA results of these four 
indicators of power relations at local level as a function of educational status of household head and region (other background variables were not considered since they did not produce significant effects).

Table 4. Mean scores and standard deviations (SDs) of indicators of power-relations $(\mathrm{N}=518)$.

\begin{tabular}{|c|c|c|c|c|}
\hline Indicators & Region & Mean & SD & $\mathbf{N}$ \\
\hline \multirow{4}{*}{ 1.Local authorities are accountable to the local people } & Oromia & 4.24 & 0.59 & 208 \\
\hline & Amhara & 3.42 & 0.70 & 159 \\
\hline & SNNPRS & 4.15 & 0.88 & 151 \\
\hline & Total & 3.73 & 0.82 & 518 \\
\hline \multirow{4}{*}{ 2. Local people have the right to set agenda on local matters } & Oromia & 3.25 & 0.92 & 208 \\
\hline & Amhara & 2.80 & 0.78 & 159 \\
\hline & SNNPRS & 3.62 & 1.08 & 151 \\
\hline & Total & 3.22 & 0.98 & 518 \\
\hline \multirow{4}{*}{ 3.Local people have full right to make decisions on local matters } & Oromia & 3.44 & 0.93 & 208 \\
\hline & Amhara & 3.08 & 0.81 & 159 \\
\hline & SNNPRS & 3.62 & 1.07 & 151 \\
\hline & Total & 3.38 & 0.96 & 518 \\
\hline \multirow{4}{*}{$\begin{array}{l}\text { 4.The local authorities properly keep peace and security so that the crime } \\
\text { rate is low }\end{array}$} & Oromia & 3.65 & 0.73 & 208 \\
\hline & Amhara & 3.42 & 0.70 & 159 \\
\hline & SNNPRS & 4.15 & 0.88 & 151 \\
\hline & Total & 3.73 & 0.82 & 518 \\
\hline
\end{tabular}

Source: Survey data by the authors (2011/2012).

As depicted in Table 5, households differed to a significant degree with respect to their educational status and region in assessing power relations at the local level. For instance, regional variations were found to affect households' perceptions of the level of accountability that local politicians have to their constituencies $(\mathrm{F}[2517]=23.92, p<0.01$, eta squared $=0.086)$ and local peoples' rights to set agendas on issues of local interest $(\mathrm{F}[2517]=7.59, p<0.01$, eta squared $=0.029)$. In other words, the three regions of Amhara, Oromia, and SNNPR were not uniform. As shown earlier in Table 4, the mean scores for the indicated first and third items show that the lowest mean ratings were consistently observed in Amhara, followed by Oromia while SNNPR had the highest scores, except in the case of the first item "accountability of local officials" where Oromia (mean $=4.24, \mathrm{SD}=0.59$ ) slightly exceeded SNNPR (mean $=4.15, \mathrm{SD}=0.88$ ). Both parts of Figure 3 illustrate the trend that the Amhara region generally gave the lowest ratings. 


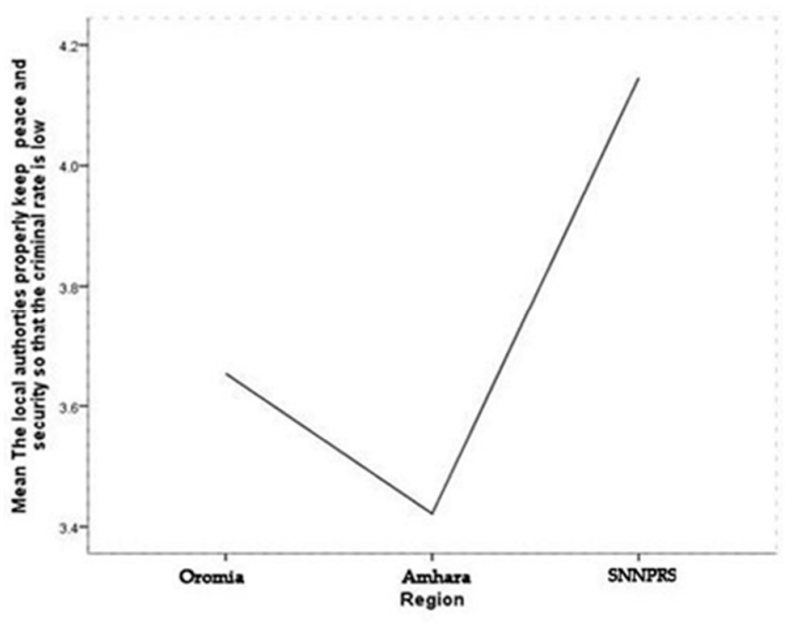

(a)

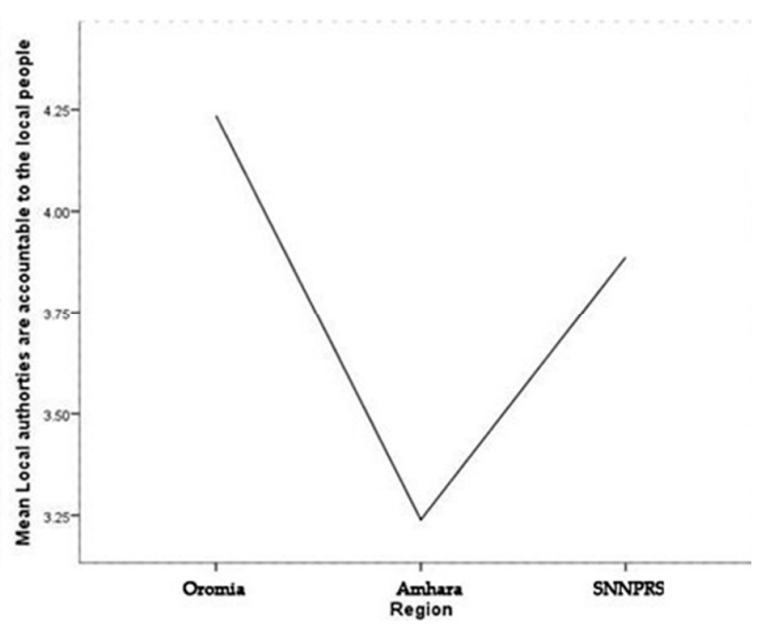

(b)

Figure 3. Regional difference in households' views of power relations; source: survey data by the authors $(2011 / 12)$.

Table 5. Effects of education and regional variation on assessing aspects of power relations at local level $(\mathrm{N}=518)$.

\begin{tabular}{|c|c|c|c|}
\hline & F & Sig. & Partial eta Squared \\
\hline \multicolumn{4}{|c|}{ Local authorities are accountable to the local people } \\
\hline Region & 23.92 & 0.000 & 0.086 \\
\hline Educational Status & 2.69 & 0.046 & 0.016 \\
\hline Educational Status $x$ Region & 5.19 & 0.000 & 0.058 \\
\hline \multicolumn{4}{|l|}{ a. $R$ squared $=0.300$ (adjusted $r$ squared $=0.285)$} \\
\hline \multicolumn{4}{|c|}{ Local people have full right to make decisions on local matters } \\
\hline Region & 1.102 & 0.333 & 0.004 \\
\hline Educational Status & 3.401 & 0.018 & 0.020 \\
\hline Educational Status $x$ Region & 2.166 & 0.045 & 0.025 \\
\hline \multicolumn{4}{|l|}{ a. $R$ squared $=0.098$ (adjusted $r$ squared $=0.078$ ) } \\
\hline \multicolumn{4}{|c|}{ Local people have the right to set agenda on local matters } \\
\hline Region & 7.59 & 0.001 & 0.029 \\
\hline Educational status & 3.56 & 0.014 & 0.021 \\
\hline Region $x$ Educational Status & 1.49 & 0.188 & 0.017 \\
\hline \multicolumn{4}{|l|}{ a. $R$ squared $=0.140$ (adjusted $r$ squared $=0.121$ ) } \\
\hline \multicolumn{4}{|c|}{ Local authorities properly keep peace and security so that the crime rate is low } \\
\hline Region & 0.657 & 0.519 & 0.003 \\
\hline Educational status & 4.06 & 0.007 & 0.024 \\
\hline Region $\mathrm{x}$ Educational Status & 1.829 & 0.092 & 0.021 \\
\hline a. $R$ squared $=0.164$ (adjusted $r$ squared $=0.146)$ & & & \\
\hline
\end{tabular}

Source: Survey data by the authors 2011/2012.

The disaggregated data with respect to educational status depicted in Figure 4 shows a clear pattern that with an increased level of education, households perceived a decline in the accountability of local officials. 


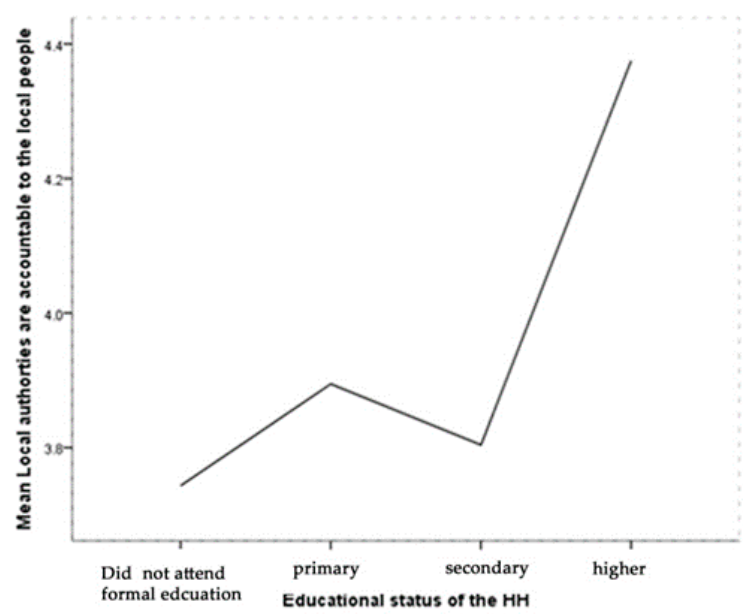

(a)

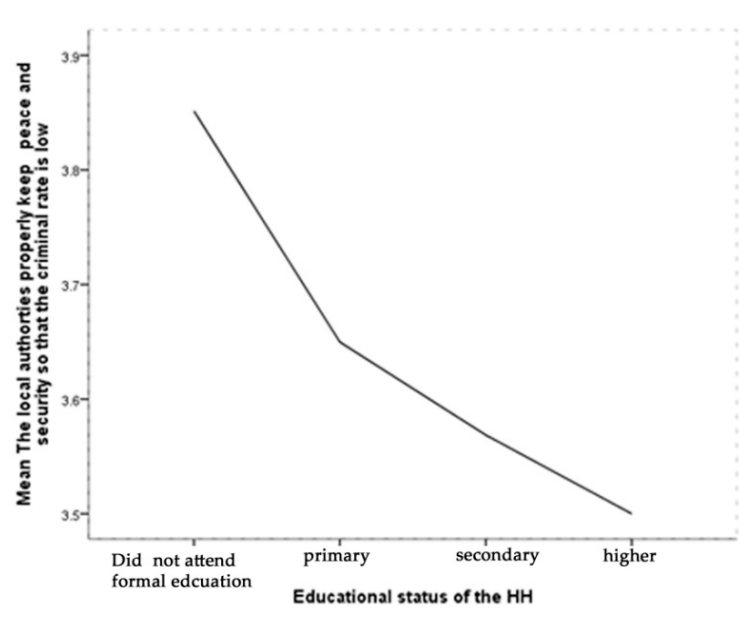

(b)

Figure 4. Households' views of power relations based on their educational status; source: survey data by the authors $(2011 / 12)$.

Regarding access to and control over the means of violence, the state has effective control of both aspects in all the three regions. The local people are not allowed to possess any kind of firearms. The state, via paratroopers and local militia, effectively maintains social order and security in all localities. In fact, there is some recorded evidence of homicides a few years earlier in and around Deberberhan, perpetuated by the possession of light weapons. However, the trend of crime has significantly reduced after the introduction of popular organizations and community policing services. According to one farmer interviewee in Goshebado:

Few years back there was a serious security problem. But nowadays the security situation is significantly improved. The popular organizations and the introduction of community policing are the reasons for improved security in our locality. We do not have any security problem. The security of our neighborhood is effectively maintained by local security forces and the people themselves [63].

In fact, there were speculations about circulation and possession of illegal weapons obtained from demobilized armies of the previous regimes. Nevertheless, the state effectively reinforces empirical statehood and controls all territories in the study areas. As a result, armed resistance or peasant rebellions have not occurred in any of the rural localities in the study areas before and during the study period.

As depicted in Table 1, nearly half of the respondents agreed on the state's capacity to promote security and have effective control over the means of violence. Accordingly, $13.7 \%(\mathrm{~N}=71)$, strongly agreed, $29.7 \%(\mathrm{~N}=154)$ agreed while $1.7 \%(\mathrm{~N}=9)$ strongly disagreed and $15.4 \%(\mathrm{~N}=80)$ disagreed. The proportion of those who were undecided $(39.4 \%, \mathrm{~N}=204)$ was nearly equal to those who either agreed or strongly agreed. On the other hand, the statistical analysis (see Table 2) revealed that, regardless of regional differences, the majority of the households did not endorse the idea that "The local authorities properly keep peace and security so that the crime rate is low" (mean $=3.73$, $\mathrm{SD}=0.82 ; \mathrm{t}(517)=-7.64, p<0.05)$. As illustrated in Figure $3 \mathrm{~b}$, small regional differences are evident where the highest rating was found in the case of SNNPR while the lowest was observed in the case of Amhara, even though the ANOVA test did not show statistical significance $(F[2515]=0.657, n s)$. On the other hand, though the effect of educational status on perception of control over means of violence is statistically significant $(\mathrm{F}[2515]=4.06, p<0.05$, eta squared $=0.027)$, there is no clear pattern in the respondents' views with an increase or decrease in educational status as shown in Figure $4 \mathrm{~b}$. In other words, respondents having secondary education showed lower scores than those with primary education, while those having higher education scored the highest of all groups. 


\section{Conclusions}

The post-1991 political transformation can be classified under four broad phases: transition (1991-1997), consolidation (1998-2005), domination (2006-2010) and contestation (2011-present). State-Society relations unveil a new dynamic of the restructuring of state under ethnic federalism and entitling self and shared rights to various ethnic groups under the new ethnic-based federal state structure.

Our analysis shows that the state-society relations in Ethiopia are driven by three major factors. The first of these is property rights, mainly regarding the question of land tenure, which occupies the central place in state-society relations. The state retains monopoly over land and property rights as an effective means of political control. The struggle to secure full rights over property and land resulted in political and regime change in 1974 and 1991. However, to date, the controversy surrounding property rights has not yet been yet resolved.

Second, political representation that has been articulated as the "nationality question" since the mid-1960s is also at the heart of national politics. Since 1991, the Ethiopian Peoples Revolutionary Democratic Front EPRDF-led government has introduced ethnicity-based federalism as a new formula of power brokering among the competing actors based on ethnic representation at national and regional levels. However, the contestations on political settlement remain unresolved.

Third, the urban-rural divide is another major factor, which manifested itself via competing, often irreconcilable interests of the urban and rural elite. The urban elite represents a group of intellectuals who tend to be urban-based and have pan-Ethiopian sentiments under cultural assimilations of Ethiopianism. The rural elite, on the other hand, embodies the political elite who are from a rural background and have a sentiment of ethnicity under cultural pluralism. The urban elite is mostly in the opposition camp and the rural elites run the state machinery under the incumbent government at national and local levels. Their contention and intermittent struggle for power shapes and dictates state-society relations. However, this antagonism has not hitherto been recognized as a driving force of state-society relations among academia. The divide unveils a struggle for control over the state, which complicates the state-society relations along urban and rural fault lines.

The political relations of local people with the state signify mutual relations. We have examined the local people's relations with the state, taking into account two major variables of perception and practice of state, together with other variables such as symbols, social control, decision-making and control over the means of violence.

The findings reveal that the local people claim to have the ability and full right to make decisions on their local matters but do not have the ability to exert control over the means of violence. The symbol of the state is well-embedded in the rural realm. Local villagers have developed a perception that considers the state as all-powerful. Regarding social control, the state has weakened all competing forces, including the church, in effectively controlling the power infrastructure through complicated organizations that extend to the household level which give preeminent political control over the society. Therefore, the state wields discretionary power to decide on all matters in Ethiopia.

Author Contributions: Yeshtila W. Bekele selected the topic; designed the study; collected and analyzed the field data; conducted literature review; developed framework of analysis; discussed with co-authors and wrote the first draft of the article. The draft was shared with co-authors for comments and submitted to the journal. Darley J. Kjosavik Commented on and contributed to the theoretical framework, analysis and finalization of the article. Nadarajah Shanmugaratnam Commented on and contributed to the theoretical framework, analysis and finalization of the article.

Conflicts of Interest: The authors declare no conflict of interest.

\section{References}

1. Markakis, John. Ethiopia: The Last Two Frontiers. Rochester: James Currey, 2011.

2. Tesfaye, Aaron. Political Power and Ethnic Federalism: Struggle for Democracy in Ethiopia. Maryland: University press of America, 2002. 
3. Tamrat, Taddesse. Church and State in Ethiopia, 1270-1527. New York: Clarendon Press, 1972.

4. Tibebu, Teshale. The Making of Modern Ethiopia, 1896-1974. Lawrenceville: The Red Sea Press, 1995.

5. Zewede, Bahru. The History of Modern Ethiopia, 1855-1974. London: James Carrey, 1991.

6. Tareke, Gebru. Ethiopia: Power and Protest: Peasant Revolts in the Twentieth Century. Lawrenceville: The Red Press, 1996.

7. Berhe, Aregawi. A Political History of the Tigray People's Liberation Front (1975-1991): Revolt, Ideology and Mobilisation in Ethiopia. Los Angles: Tsehai Publishers, 2009.

8. WoldeMariam, Mesfin M. Rural Vulnerability to Famine in Ethiopia: 1958-1977. New Delih: Vikas Publishing House, 1984.

9. Migdal, Joel S. State in Society: Studying How States and Societies Transform and Constitute One Another. Cambridge: Cambridge University Press, 2001.

10. Mitchell, Timothy. "The Limits of the State: Beyond Statist Approaches and Their Critiques." American Political Science Review 85 (1991): 77-96. [CrossRef]

11. Sørensen, Georg. The Transformation of the State: Beyond the Myth of Retreat. New York: Palgrave MacMillan, 2004.

12. Sellers, Jefferey M., and Sun-Young Kwak. "State and Society in Local Governance: Lessons from a Multilevel Comparison." International Journal of Urban and Regional Research 35 (2010): 620-43. [CrossRef]

13. Migdal, Joel S. Strong Societies and Weak States: State-Society Relations and State Capabilities in the Third World. Princeton: Princeton University Press, 1988.

14. Wrong, Dennis H. Power. New Brunswick. Piscataway: Transaction Publishers, 1995.

15. Wrong, Dennis H. Power: Its Forms, Bases and Uses. Piscataway: Transaction Books, 1988.

16. Thomson, Janice E. "State sovereignty in international relations: Bridging the gap between theory and empirical research." International Studies Quarterly 39 (1995): 213-33. [CrossRef]

17. Layder, Derek "Power, Structure and Agency." Journal for the Theory of Social Behavior 15 (1985): 131-49. [CrossRef]

18. Mann, Michael "The autonomous power of the state: Its origins, mechanisms and results." European Journal of Sociology 25 (1984): 185-213. [CrossRef]

19. Tronvoll, Kjetil, and Tobias Hagmann. Contested Power in Ethiopia: Traditional Authorities and Multiparty Election. Leiden: Bril, 2012.

20. Vaughan, Sarah. "Revolutionary democratic state-building: Party, state and people in the EPRDF's Ethiopia." Journal of Eastern African Studies 5 (2011): 619-40. [CrossRef]

21. Abbink, Jon. "Ethnic-based federalism and ethnicity in Ethiopia: Reassessing the experiment after 20 years." Journal of Eastern African Studies 5 (2011): 596-618. [CrossRef]

22. Vaughan, Sarah, and Kjetil Tronvoll. The Culture of Power in Contemporary Ethiopian Political Life. Stockholm: Swedish International Development Cooperation Agency, 2003.

23. Fasil, Nahum. Constitution for a Nation of Nations: The Ethiopian Prospect. Lawrenceville and Asmara: The Red Sea Press, 1997.

24. Aalen, Lovise. "Ethnic Federalism in a Dominate Party State: the Ethiopian Experience 1991-2000." In Development Studies and Human Rights Report. Christainsend: Bergen Michelson Institute, 2002.

25. Fiseha, Assefa. Federalism and Accommodation of Diversity in Ethiopia: A Comparative Study. Utrecht: Wolf Legal Publisher, 2007.

26. Turton, David. Ethnic Federalism: The Ethiopian Experience in Comparative Perspective. Oxford: James Currey, 2006.

27. Van der Beken, Christophe. "Ethiopia: Constitutional Protection of Ethnic Minorities at the Regional Level." Afrika Focus 20 (2007): 105-51.

28. Abbay, Alemseged. "Diversity and State Building in Ethiopia." African Affairs 103 (2004): 593-614. [CrossRef]

29. Vestal, Theodore M. Ethiopia: A Post-Cold War African State. London: Praeger, 1999.

30. Pausewang, Siegfried, Kjetil Tronvoll, and Lovise Aalen. Ethiopia Since the Derg: A Decade of Democratic Pretensions and Performance. London: Zed books, 2002.

31. Gudina, Merera. Ethiopia: Competing Ethnic Nationalisms and the Quest for Democracy, 1960-2000. Addis Ababa: Chamber Printing House, 2003.

32. Tadesse, Medhane, and John Young. "TPLF: Reform or decline?" Review of African Political Economy 30 (2003): 389-403. [CrossRef] 
33. Clapham, Christopher. "Post-War Ethiopia: The Trajectories of Crisis." Review of African Political Economy 30 (2009): 181-92. [CrossRef]

34. Lefort, René. "Powers-Mengist—and Peasants in Rural Ethiopia: The May 2005 Elections." The Journal of Modern African Studies 45 (2007): 253-73. [CrossRef]

35. Aalen, Lovise. The Politics of Ethnicity in Ethiopia: Actors, Power and Mobilisation under Ethnic Federalism. Leiden: Brill, 2011.

36. Balsvik, Randi Rønning. Haile Selassie's Students: The Intellectual and Social Background to Revolution: 1952-1974. Addis Ababa: Addis Ababa University Press, 2005.

37. Zewde, Bahru, ed. Documenting the Ethiopian Student Movement: An Exercise in Oral History. Addis Ababa: Fourm for Social Studies, 2010.

38. Tareke, Gebru. The Ethiopian Revolution: War in the Horn of Africa. New Haven and London: Yale University Press, 2009.

39. The Provisional Military Council of Ethiopia. "Negarit Gazeta-A Proclamation to Provide for Government Ownership of Urban Lands and Extra Urban Houses. No. 41." 26 July 1975. Available online: http:/ /faolex.fao.org/cgibin/faolex.exe?database=faolex\&search_type=link\&table=result\&lang= eng\&format_name=@ERALL\&rec_id=001827 (accessed on 15 August 2016).

40. The Provisional Military Council of Ethiopia. "Negarit Gazeta-A Proclamation to Provide for the Public Ownership of Rural Lands. No. 31.” 26 July 1975. Available online: http:/ / faolex.fao.org/cgibin/faolex. exe?rec_id=001828\&database=faolex\&search_type=link\&table=result\&lang=eng\&format_name=@ERALL (accessed on 15 August 2016).

41. Keller, Edmond J. "Constitutionalism, Citizenship and Political Transition in Ethiopia: Historic and Contemporary Process." In Self-Determination and National Unity: A Challenge for Africa. Edited by Francis M. Deng. Trenton: World Press, 2010.

42. Keller, Edmond J. "Federalsim, citizenship and national identity in Ethiopia." The International Journal of African Studies 6 (2007): 38-70.

43. Hoben, Allen. Land Tenure among the Amhara of Ethiopia:The Dynamics of Cognatic Descent. Chicago: University of Chicago Press, 1973.

44. Cohen, John M., and Dov Weintraub. Land and Peasants in Imperial Ethiopia. The Social Background to a Revolution. Assen: Van Gorcum \& Comp., 1975.

45. Pausewang, Siegfri. Peasants, Land and Society: A Social History of Land Reform in Ethiopia. Munchen: Weltfourm Verlag, 1983.

46. Joireman, Sandra F. Property Rights and Political Development in Ethiopia and Eritrea 1941-74. Athens: Ohio University Press, 2000.

47. Kebede, Teketel Abebe. "Tenants of the State: The Limitations of Revolutionary Agrarian Transformation in Ethiopia, 1974-1991." Ph.D. Dissertation, Department of Sociology, Lund University, Lund, Sweden, 4 June 1998.

48. Rahmato, Dessalegn. The Peasant and the State: Studies in Agrarian Change in Ethiopia 1950-2000's. Addis Ababa: Addis Ababa University Press, 2009.

49. Crummey, Donald. Land and Society in the Christian Kingdom of Ethiopia: From the Thirteenth to the Twentieth Century. Champaign: University of Illinois Press, 2000.

50. A politician and academic (Addis Ababa, Ethiopia). Interview, 2012.

51. Shepperson, George. "Ethiopianism and African Nationalism." Phylon 14 (1953): 9-18. [CrossRef]

52. Jalata, Assefa. "Being in and out of Africa: The Impact of Duality of Ethiopianism." Journal of Black Studies 40 (2009): 189-214. [CrossRef]

53. Aalen, Lovise, and Kjetil Tronvoll. "The End of Democracy? Curtailing Political and Civil Rights in Ethiopia." Review of African Political Economy 36 (2009): 193-207. [CrossRef]

54. WoldeMariam, Mesfin. Suffering under God's Environment: A Vertical Study of the Predicament of Peasants in North-Eastern Ethiopia. Berne: Geographica Bernenisa, 1991.

55. A peasant (Gerema Kebele, Jimma area, Ethiopia). Interview, 2012.

56. A peasant (Alyu Amba Kebele, Debere Berhan area, Ethiopia). Interview, 2012.

57. Hobbes, Thomas. Leviathan. NewYork: Continuum Publishing, 2005.

58. Ege, Svein Einar. Class, State and Power in Africa: A Case Study of Kingdom of Shawa (Ethiopia) about 1840. Wiesbaden: Otto Harrassowitz, 1996. 
59. Poluha, Eva, and Mona Rosendahl. Learning Political Behavior: Peasant-State Relations in Ethiopia in Poluha, E E Rosendahl, Mona Contesting "Good" Governance. London: Routledge, 2002.

60. Lefort, René. "Powers-Mengist-And peasants in rural Ethiopia: The post-2005 interlude." The Journal of Modern African Studies 48 (2010): 435-60. [CrossRef]

61. A peasant (Dawa Kebele, Jimma Area, Ethiopia). Interview, 2012.

62. A peasant (Amara ena Bodo, Gamo Area, Ethiopia). Focus group discussion, 2012.

63. A peasant (Goshe Bado, Debere Berhan area, Ethiopia). Interview, 2012.

(C) 2016 by the authors; licensee MDPI, Basel, Switzerland. This article is an open access article distributed under the terms and conditions of the Creative Commons Attribution (CC-BY) license (http:/ / creativecommons.org/licenses/by/4.0/). 